\title{
JOURNAL OF APPLIED PROBABILITY \\ VOLUME 52 (2015): INDEX
}

ACAN, H. AND HitCZENKo, P. On the covariances of outdegrees in random plane recursive trees . .

Anceaume, E., Busnel, Y. and Sericola, B. New results on a generalized coupon collector

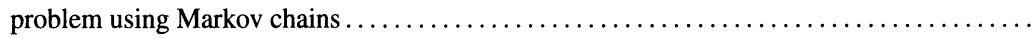

ANDRIEU, C., ForT, G. AND ViHOLA, M. Quantitative convergence rates for subgeometric Markov

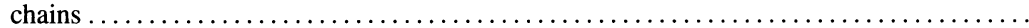

Applebaum, D. ANd Blackwood, S. The Kalman-Bucy filter for integrable Lévy processes with

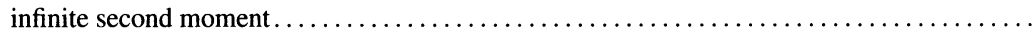

Asadi, M. see Ashrafi, S.

Ashrafi, S. AND Asadi, M. Letter to the Editor: On Ashrafi and Asadi (2014) ..............

ATCHADÉ, Y. F. AND WANG, Y. On the convergence rates of some adaptive Markov chain Monte

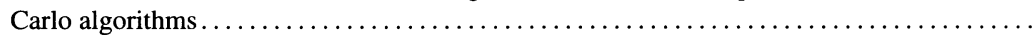

AthreyA, K. B. AND RoY, V. Estimation of integrals with respect to infinite measures using

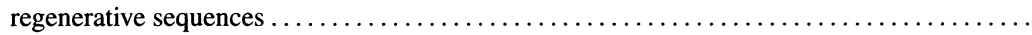

BaCKhausz, Á. AND Móri, T. F. Asymptotic properties of a random graph with duplications .....

BADÍA, F. G. AND SANGÜESA, C. The DFR property for counting processes stopped at an independent

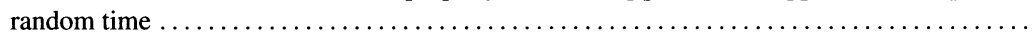

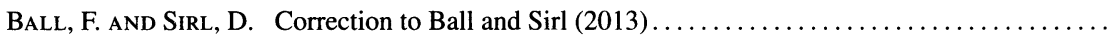

BARRON, Y. A fluid EOQ model with Markovian environment $\ldots \ldots \ldots \ldots \ldots \ldots \ldots \ldots \ldots \ldots$

BartoszeK, K. AND Sagitov, S. Phylogenetic confidence intervals for the optimal trait value ....

BAUMANN, H. AND SANDMANN, W. Bounded truncation error for long-run averages in infinite Markov

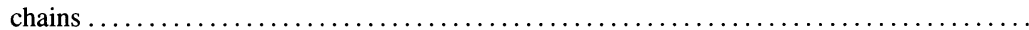

Bean, N. G., Elliott, R. J., Eshragh, A. and Ross, J. V. On binomial observations of continuous-

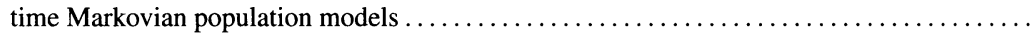

Beghin, L., Garra, R. AND MaCCI, C. Correlated fractional counting processes on a finite-time interval...

Bender, C., Pakkanen, M. S. and Sayit, H. Sticky continuous processes have consistent price

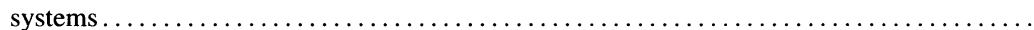

Blackwood, S. see Applebaum, D.

Block, H. W., Naftali, A., Langberg, N. A. and Savits, T. H. The limiting failure rate for a

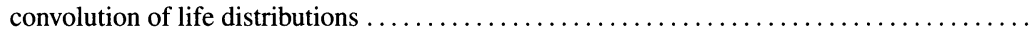

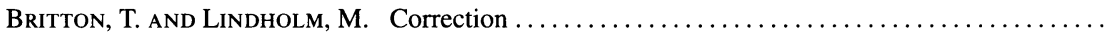

BROWN, M. Sharp bounds for exponential approximations under a hazard rate upper bound......

Budhiraja, A. AND NyQuist, P. Large deviations for multidimensional state-dependent shot-noise processes

BUONAGUIDI, B. A remark on optimal variance stopping problems

PAGES

904-907

$405-418$

$391-404$

636-648

305-305

811-825

$1133-1145$

375-390

574-585

908-908

473-489

1115-1132

609-621

457-472

1045-1061

586-594

894-898

1202-1203

841-850

1097-1114

1187-1194

167-179

Busnel, Y. see AnCEAume, E.

CAstro, I. T. see CHA, J. H.

Cavazos-Cadena, R., Montes-De-Oca, R. and Sladký, K. Sample-path optimal stationary policies in stable Markov decision chains with the average reward criterion . . . . . . . . . .

Cha, J. H. ANd CAstro, I. T. A stochastic failure model with dependent competing risks and its

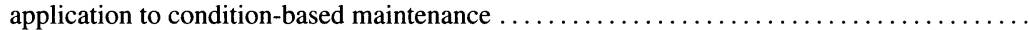

$419-440$

$558-573$ 941-961

ChaO, X., He, Q. -M. AND Ross, S. M. Tollbooth tandem queues with infinite homogeneous servers 
Cheng, L. -J. and Mao, Y. -H. Eigentime identity for one-dimensional diffusion processes ......

Cohen, S. N. see Elliott, R. J.

Crane, H. and Mccullagh, P. Poisson superposition processes $\ldots \ldots \ldots \ldots \ldots \ldots \ldots \ldots \ldots$

- AND — Reversible Markov structures on divisible set partitions .

D'Andrea, A. AND DE SANCTIS, L. The Kruskal-Katona theorem and a characterization of system signatures

$508-518$

DE SANCTIS, L. see D'ANDREA, A.

DȩBicki, K., Hashorva, E. ANd Soja-Kukiela, N. Extremes of homogeneous Gaussian random

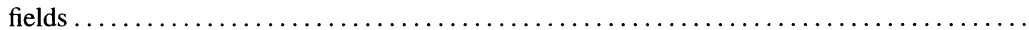

- - _ - AND Ji, L. Parisian ruin of self-similar Gaussian risk processes $\ldots \ldots \ldots \ldots \ldots \ldots \ldots$

Debrabant, K. And Rößler, A. On the acceleration of the multi-level Monte Carlo method .....

Decreusefond, L., Flint, I. AND Vergne, A. A note on the simulation of the Ginibre point process

DESHPANDE, A. On the role of Follmer-Schweizer minimal martingale measure in risk-sensitive

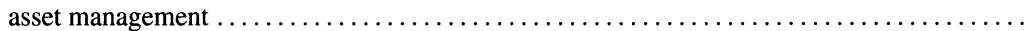

Di Crescenzo, A., Martinucci, B. and Zacks, S. Compound Poisson process with Poisson subordinator.

AND ToOmaJ, A. Extension of the past lifetime and its connection to the cumulative entropy. .

Durante, F., Fernández-SÁnchez, J. AND Trutschnig, W. On the singular components of a

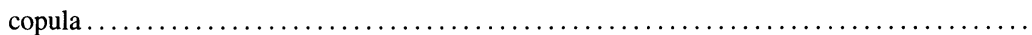

Egozcue, M. AND Garcia, L. F. An optimal threshold strategy in the two-envelope problem with partial information .

El-Desouky, B. S., Shiha, F. A. AND MaGar, A. M. On a generalization of a waiting time problem

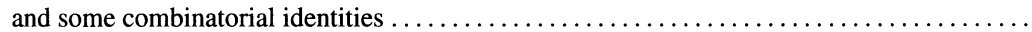

Elliott, R. J., SiU, T. -K. AND Cohen, S. N. Backward stochastic difference equations for dynamic convex risk measures on a binomial tree. see BEAN, N. G.

ERYilmaz, S. Component importance in coherent systems with exchangeable components ......

Eshragh, A. see BEAN, N. G.

FAlK, M., HofmanN, M. AND ZotT, M. On generalized max-linear models and their statistical

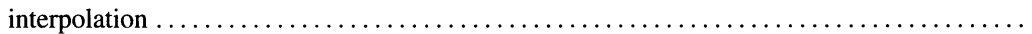

FATHEDDIN, P. Central limit theorem for a class of SPDEs $\ldots \ldots \ldots \ldots \ldots \ldots \ldots \ldots \ldots \ldots \ldots \ldots$

FERnández-SÁnchez, J. see Durante, F.

Ferreiro-Castilla, A. and Van Schaik, K. Applying the Wiener-Hopf Monte Carlo simulation

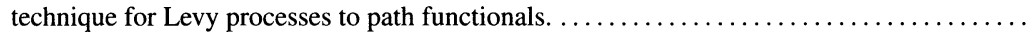

Fierro, R., Leiva, V. ANd Møller, J. The Hawkes process with different excitation functions and its asymptotic behavior

$37-54$

Flint, I. see DeCREUSEFond, L.

FORT, G. see ANDRIEU, C.

FoxALl, E. New results for the two-stage contact process $\ldots \ldots \ldots \ldots \ldots \ldots \ldots \ldots \ldots \ldots \ldots$

Frostig, E. The moments of the discounted loss and the discounted dividends for a spectrally

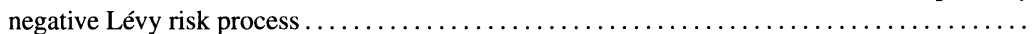

Garcia, L. F. see Egozcue, M.

Garra, R., Orsingher, E. And Polito, F. State-dependent fractional point processes ........... see BEGHIN, L.

Guillemin, F. M. and Mazumdar, R. R. Conditional sojourn times and the volatility of payment schemes for bandwidth sharing in packet networks $\ldots \ldots \ldots \ldots \ldots \ldots \ldots \ldots \ldots \ldots \ldots$ AND SERICOLA, B. Volume and duration of losses in finite buffer fluid queues............

Guo, X. see Wu, X.

HAJI, B. AND Ross, S. M. A queueing loss model with heterogeneous skill based servers under idle

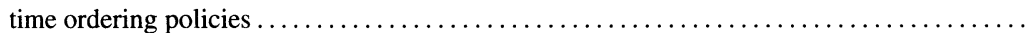

HASHorva, E. see DeBICKI, K.

HE, Q. -M. see Chao, X.

Hitczenko, P. see ACAN, H.

Hofmann, M. see FALK, M.

Holst, L. AND Konstantopoulos, T. Runs in coin tossing: a general approach for deriving distributions for functionals 
Huber, M. AND Marić, N. Multivariate distributions with fixed marginals and correlations....... $602-608$

JANSON, $S$. On degenerate sums of $m$-dependent variables $\ldots \ldots \ldots \ldots \ldots \ldots \ldots \ldots \ldots \ldots \ldots$ $1146-1155$

JASRA, A. On the behaviour of the backward interpretation of Feynman-Kac formulae under verifiable

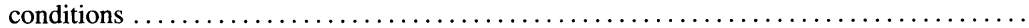

Jenkins, P. A. see Koskela, J.

JI, L. see DEBICKI, K.

JIANG, Z. Optimal dividend policy when cash reserves follow a jump-diffusion process under Markov-

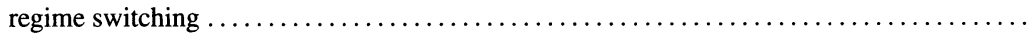

Kalinkin, A. V. And Mastikhin, A. A limit theorem for Weiss epidemic process ............

KamińSKA-ZabierowsKa, M. AND NAVARro, J. Erratum to: Mixture representations of residual

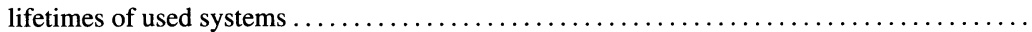

KaWANISHI, K. AND TAKINE, T. A note on the virtual waiting time in the stationary $\mathrm{PH} / \mathrm{M} / \mathrm{c}+\mathrm{D}$ queue

KIM, Y., Koprulu, I. AND Shroff, N. B. First exit time of a Lévy flight from a bounded region

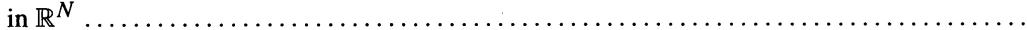

209-223

$1183-1186$

899-903

KImMEL, M. see MCDONALD, T. O.

Kochar, S. C. see TorRado, N.

Kolokoltsov, V. Stochastic monotonicity and duality of $k$ th order with application to put-call

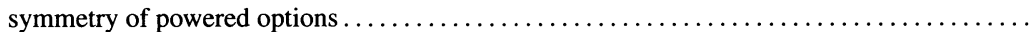

Konstantopoulos, T. see Holst, L.

Koprulu, I. see KIM, Y.

Kosinski, K. M. AND MANDJES, M. R. H. Logarithmic asymptotics for multidimensional extremes

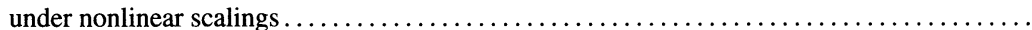

Koskela, J., Jenkins, P. A. AND Spanò, D. Computational inference beyond Kingman's coalescent

Kovács, M., LARSSON, S. AND LINDGREN, F. On the backward Euler approximation of the stochastic

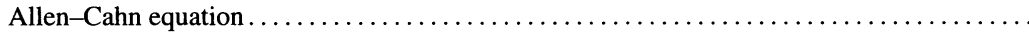

LAMBERT, A. AND MA, C. The coalescent in peripatric metapopulations $\ldots \ldots \ldots \ldots \ldots \ldots \ldots$

Landriault, D., Li, B. AND Zhang, H. On the frequency of drawdowns for Brownian motion

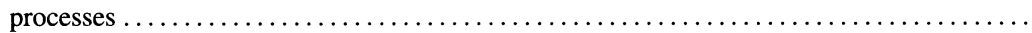

LANGBERG, N. A. see Block, H. W.

LARSSON, S. see Kovács, M.

LeIVA, V. see FIERro, R.

Li, B. see LANDRIAULT, D.

LI, J. see ZHANG, L.

LindGREN, F. see Kovács, M.

LINDHOLM, M. see BRITTON, T.

LiU, Q. see VATUtin, V. A.

MA, C. see LAMBERT, A.

MACCI, C. see BEGHIN, L.

Magar, A. M. see El-Desouky, B. S.

MAhmoud, H. M. AND WARD, M. D. Asymptotic properties of protected nodes in random recursive

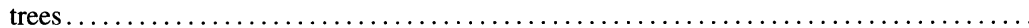

MANDJES, M. R. H. see Kosinski, K. M.

$290-297$

MAO, Y. -H. see CHENG, L. -J.

MARIĆ, N see HUBER, M.

MARICHAL, J. -L. Algorithms and formulae for conversion between system signatures and reliability functions.

$490-507$

Martinucci, B. see Di Crescenzo, A.

Mastikhin, A. see Kalinkin, A. V.

MAZUMdar, R. R. see GUILlemin, F. M.

Mccullagh, P. see Crane, $\mathrm{H}$.

MCDONALD, T. O. AND Kimmel, M. A multitype infinite-allele branching process with applications

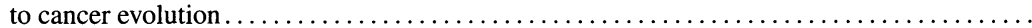

Mujatović, A., Pistorius, M. R. AND Stolte, J. Randomisation and recursion methods for mixed-

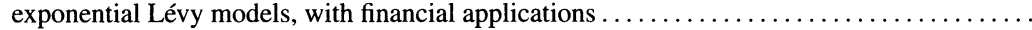

Miziula, P. AND Rychlik, T. Extreme dispersions of semicoherent and mixed system lifetimes. .

$323-338$

538-557

$191-208$

MøLler, J. see Fierro, R. 
Montes-De-Oca, R. see Cavazos-Cadena, R.

Móri, T. F. see BACKhausz, Á.

Muliere, P. see Buonaguidi, B.

Naftali, A. see Block, H. W.

NAVARro, J. see KAMINSKA-ZABIERowsKa, M.

Nyquist, P. see Budhiraja, A.

Orsingher, E. AND TOALDO, B. Counting processes with Bernstein intertimes and random jumps.

- see GARRA, R.

PAKKANEN, M. S. see Bender, C.

PIHLSGÅR, M. Local martingales with two reflecting barriers . .

$1062-1075$

Pistorius, M. R. see Mijatović, A.

Polito, F. see GARra, R.

RößLER, A. see Debrabant, K.

Ross, J. V. see BeAn, N. G.

Ross, S. M. see HAJI, B.

- see CHAO, X.

Roueff, F. ANd Soulier, P. Convergence to stable laws in the space $\mathscr{D}$

Roy, V. see Athreya, K. B.

RYCHLIK, T. see MizIUla, P.

SAGItov, S. see BARTOSZEK, $\mathrm{K}$.

SANDMANN, W. see BaUmanN, H.

SANGÜESA, C. see BADÍA, F. G.

SAVITS, T. H. see Block, H. W.

SAYIT, H. see BENDER, C.

Schulte-Geers, E. and Stadje, W. Maximal percentages in Pólya's urn

Sericola, B. see Anceaume, E.

- see GuILlEMIN, F. M.

Shita, F. A. see El-Desouky, B. S.

SHrofF, N. B. see KIM, Y.

SIRL, D. see BALL, F.

SiU, T. -K. see Elliott, R. J.

Sladký, K. see Cavazos-Cadena, $\mathrm{R}$.

Soja-Kukiela, N. see Debicki, K.

SOULIER, P. see RouefF, F.

Spanò, D. see Koskela, J.

SPILIOPOULOS, K. Nonasymptotic performance analysis of importance sampling schemes for small noise diffusions.

$797-810$

Stadje, W. see Schulte-GeErs, E.

Stolte, J. see Mujatović, A.

TAKINE, T. see KaWANISHI, K.

TAMAKI, M. On the optimal stopping problems with monotone thresholds $\ldots \ldots \ldots \ldots \ldots \ldots \ldots$

TARDELLI, P. Partially informed investors: hedging in an incomplete market with default ........

Toaldo, B. see OrSINGHER, E.

Toomaj, A. see Di Crescenzo, A.

ToRrado, N. AND Kochar, S. C. Stochastic order relations among parallel systems from Weibull distributions

Trutschnig, W. see Durante, F.

VAN Doorn, E. A. Representations for the decay parameter of a birth-death process based on the

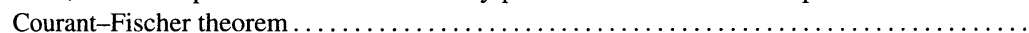

Van Schaik, K. see Ferreiro-Castilla, A.

VATUTIN, V. A. AND LiU, Q. Limit theorems for decomposable branching processes in a random

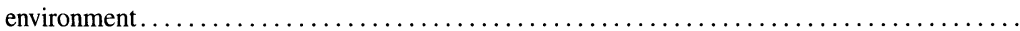

Veestraeten, D. A recursion formula for the moments of the first-passage time of the OrnsteinUhlenbeck process .

VERGNe, A. see DeCREUSEFond, L.

ViHOLA, M. see ANDRIEU, C. 
WANG, H. Euler scheme for a stochastic differential equation driven by pure jump semimartingales

WANG, Y. see ATCHADÉ, Y. F.

WARD, M. D. see MAHMOUD, H. M.

WINDRIDGE, P. The extinction time of a subcritical branching process related to the SIR epidemic

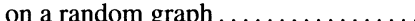

Wu, J. see $\mathrm{YAO}, \mathrm{D}$.

Wu, X. AND Guo, X. First passage optimality and variance minimization of Markov decision

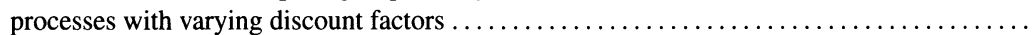

YAO, D., ChaO, X. AND WU, J. Optimal control policy for a Brownian inventory system with concave

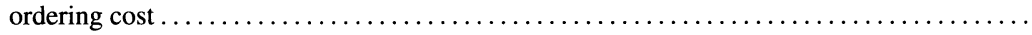

$1195-1201$

ZACKS, S. see Di Crescenzo, A.

ZhaNG, H. see LANDRIAULT, D.

Zhang, L. AND LI, J. The M/M/c queue with mass exodus and mass arrivals when empty ...

ZHOU, Y. Ergodic inequality of two-parameter infinitely-many-alleles diffusion model

238-246

ZotT, M. see FALK, M. 